\title{
The Incessant Battle Against Fire Blight in Pears: 30 Years of Challenges and Successes in Managing the Disease in Israel
}

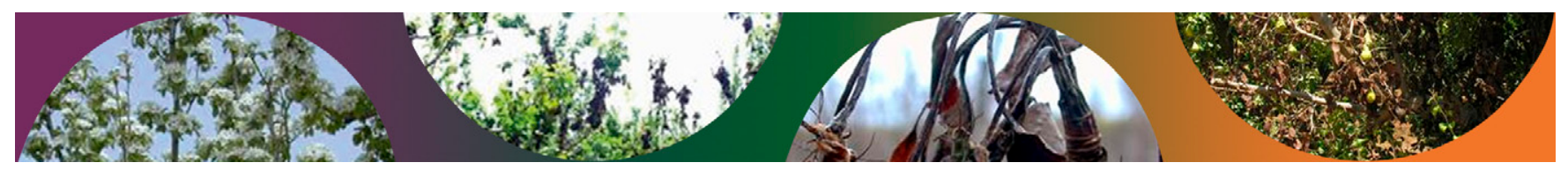

Dani Shtienberg

Department of Plant Pathology and Weed Research, ARO, The Volcani Center, Bet Dagan 50250, Israel

Shulamit Manulis-Sasson

Department of Plant Pathology and Weed Research, ARO, The Volcani Center, Bet Dagan 50250, Israel

\author{
Miriam Zilberstaine \\ R \& D North, Migal, Qiryat Shmona 11016, Israel \\ Dov Oppenheim \\ Kibbutz Daphna, 12235, Israel
}

Hagai Shwartz

Rosh Pinna, 12000, Israel

Fire blight, caused by the bacterium Erwinia amylovora (Burrill) Winslow et al. is the most destructive disease of pears (Pyrus communis L.) and other pome fruit trees worldwide (van der Zwet et al. 2012; van der Zwet and Beer 1995). The disease was first detected in Israel in 1985 (Beer et al. 1986; Zutra et al. 1986), and in the 30 years since, the intensity of fire blight epidemics has varied markedly. In some years, infections were minor and their effect on the pear industry was negligible. In others, severe infections developed in some orchards causing tree death and necessitated the occasional uprooting of orchards. During this time, two national pandemics occurred: the first between 1994 and 1996, and the second in 2010. In both cases, it was feared that the Israeli pear industry would not recover. National efforts devoted to combat the problem enabled the industry to survive both pandemics. Fire blight symptoms have also been occasionally observed on apples (Malus domestica Borkh.) in Israel. However, as infections were scarce and the damage imposed on the trees minute, this paper deals only with pears.

Numerous scientists have studied aspects related to disease etiology, epidemiology, and host-pathogen interactions over the years (e.g., Beer 1990; Johnson 2000; Johnson and Stockwell 1998; Norelli et al. 2003; van der Zwet and Beer 1995; van der Zwet et al. 2012; Vanneste 2000), and upon which we will not elaborate here. Immediately hereafter we briefly describe fire blight disease etiology and indicate some unique characteristics that play a crucial role in the epidemiology of the disease under Israeli conditions. We then describe the continual struggle of the Israeli pear industry with fire blight over the last 30 years, elaborating on the two

Corresponding author: D. Shtienberg, E-mail: danish@volcani.agri.gov.il

Accepted for publication 24 February 2015.

http://dx.doi.org/10.1094/PDIS-01-15-0101-FE

(C) 2015 The American Phytopathological Society national pandemics and the efforts devoted to cope with them. Finally, we summarize the conclusions derived from our local experience and present our future perspectives regarding fire blight management.

\section{The Disease and the Host}

E. amylovora is a gram-negative bacterium in the family Enterobacteriaceae. The pathogen overwinters in cankers formed on diseased branches in the previous season (holdover cankers). In late winter and early spring, as the winter dormancy of the host breaks and air temperatures warm, the pathogen becomes active; free bacterial cells emerge from cankers and disperse on the bark surface, sometimes as visible ooze (van der Zwet and Beer 1995). Rainfall or pollinating insects attracted to the ooze acquire and spread the bacteria from the cankers to blossoms. E. amylovora colonizes the surfaces of stigmas and, to a lesser extent, the surfaces of nectaries. This nonparasitic, epiphytic growth occurs without causing infection and disease. During this epiphytic phase, the final pathogen population size is a function of air temperature, which regulates the bacterial generation time (Thomson 2000). E. amylovora can multiply at air temperatures ranging from 5 to $37^{\circ} \mathrm{C}$, the optimal temperature being $28^{\circ} \mathrm{C}$ (Billing 1974). Blossom blight begins when cells of E. amylovora wash from the epiphytically colonized stigma to the hypanthium (floral cup). On the hypanthium, the pathogen gains entry to the plant through secretory cells (nectarthodes) located on the surface (Sherman 2000). This will be referred to hereafter as an "infection episode." As the pathogen may have epiphytically colonized numerous clusters of blossom before the occurrence of an infection episode, the outcome may be potentially devastating. If infested blossoms are not properly protected with bactericides, hundreds of blossom clusters on each tree may develop symptoms following a single infection episode (Fig. 1).

After colonizing the blossoms, E. amylovora cells invade the intercellular spaces of the cortical parenchyma and reach the phloem sieve tubes and the xylem vessels. The pathogen may then progress 
to the supporting branches and advance further down to the tree's main limbs and trunk. Infected tissues often become necrotic and may eventually die (Vanneste and Eden-Green 2000). The wilting associated with fire blight is due to parenchyma collapse. E. amylovora does not produce cell wall-degrading enzymes. Its pathogenicity is dependent on a functional type III secretion system, which enables the secretion of effector proteins into the plant cells (Bogdanove et al. 2000).

The rate of symptom progression within host tissues depends on the cultivar, environment, and age and nutritional status of the host. Young, vigorously growing tissues and trees are more susceptible to fire blight than older, more slowly growing tissues or trees. Similarly, trees receiving an excess of nitrogen fertilizer and thereby growing rapidly are more susceptible than trees fertilized with a balanced nutrient formulation (Sherman 2000). Blachinsky et al. (2006) reported that the rate of symptom progression in perennial branches was related to the content of sorbitol in the tissues. Sorbitol (D-glucitol) is the principal transport and storage carbohydrate compound for numerous plant species in the Rosaceae family, including pears (Loescher 1987). Canker expansion slows as the growth rate of the trees and shoots declines.

In the mid-1980s, when fire blight epidemics first occurred in Israel, the pear production area in Israel covered 1,500 ha, most of which (ca. 1,200 ha) was located in the north-in the western and upper Galilee, in the Hula valley, and in the Golan Heights. Pears were also grown in the center of the country in the Samaria region, the coastal plain and the inner plains (ca. $225 \mathrm{ha}$ ), and in the south-in the northern Negev (ca. 75 ha). The most common cultivars in Israeli pear orchards are Spadona, Costia, Jantil, and Spadochina, which are grafted on quince clones and pear seedling rootstocks. Tree vigor varies markedly, even in well-maintained orchards. Trees in some orchards have low vigor with few or no annual shoots on terminal branches; others have more vigor and numerous annual shoots on most terminal branches. Factors governing tree vigor include host genotype (e.g., cultivar characteristics), cultural practices (e.g., rootstock and cultivar compatibility, tree shaping), horticultural and production practices (e.g., irrigation, fertilization, pruning), and environment (e.g., temperature, precipitation).

Blooming and vegetative growth for pear occur in Israel in the spring (March to April), after the termination of winter dormancy. A second blooming period might occur in the autumn (September to November). Unlike in spring, autumn blooming is not uniform across trees and orchards, and occurs primarily in orchards or individual trees exposed to drought stress after fruit harvest (Naor et al. 2006).

\section{Disease Management: Global and Local Perspectives}

Management of fire blight is a difficult task because there are very few effective means for disease suppression. Fire blight management includes several lines of defense (van der Zwet and Beer 1995). The first is preventive: avoidance (production in areas with weather conditions unfavorable to pathogen development); choosing a suitable orchard site; proper fertilization and irrigation; tree shaping; horticultural pruning; shortening the duration of blooming; and preventing off-season blooming. If the disease has developed in an orchard previously, management efforts aim to reduce the amount of initial inoculum before bloom. For this, farmers apply foliar sprays of copper hydroxide before and during green tip, with the assumption that the compound will reduce the amount of initial inoculum. The aim of the second line of defense is to protect the blossoms from infection, and for this purpose, farmers apply bactericides or biocontrol agents during bloom. As blossom infection is sporadic from season to season and from orchard to orchard, models such as Maryblyt (Steiner 1990), Cougarblight (Smith 1999), and BIS95 (Billing 1999) predict the likelihood of infection episodes. The last line of defense activates only when disease symptoms are observed in an orchard: eradication all infected plant tissue at 30 to $40 \mathrm{~cm}$ on stems below symptoms (van der Zwet and Beer 1995).

In general, the environment $\times$ host $\times$ pathogen interactions described above are globally relevant. Nevertheless, few seemingly minor factors have significant effects on the epidemiology of the disease in Israel. With respect to the environment, the relatively favorable air temperatures prevailing in Israel during the spring promote the activity of pollinating insects that spread the bacteria in the orchard to enable epiphytic growth in open blossoms. For example, the maximum daily air temperature during March and early April of 2010 at the Rosh Pinna weather station (located in northern Israel) was above $15^{\circ} \mathrm{C}$
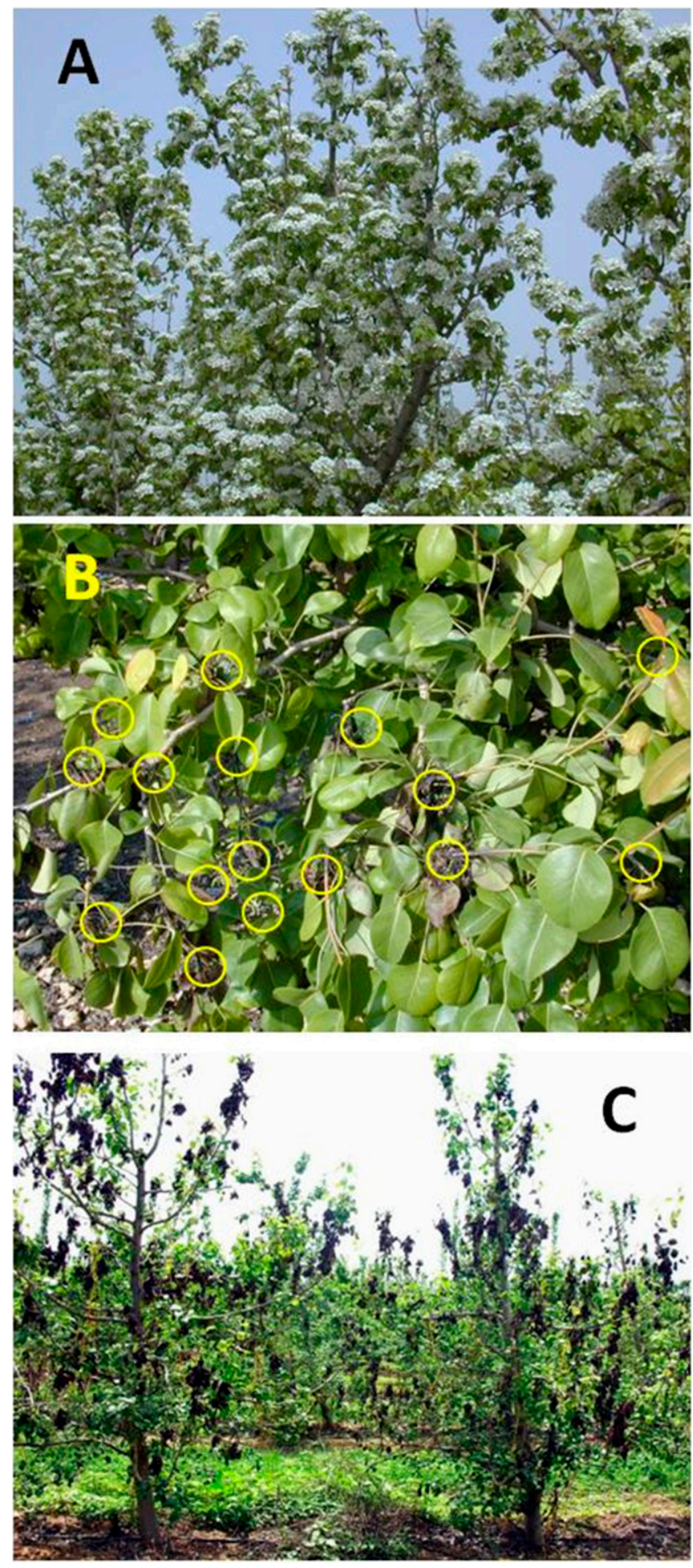

Fig. 1. A, Pear trees at full bloom. The blossoms may be colonized by Erwinia amylovora cells, inhabiting primarily the stigmas. B, Blossoms (marked by yellow circles) that were recently infected during one infection episode. C, Severe fire blight infections developed in spring 2006 in a ca. 35-ha pear orchard located in northern Israel. Infections occurred in two episodes and the farm manager did not implement the necessary actions to protect the crop. In nearby orchards, where growers acted as instructed, only a few infections were observed in the whole orchards and these were easily removed by pruning. 
on all days; the average daily temperature was above $15^{\circ} \mathrm{C}$ on 25 of the 37 days. An average daily temperature of 15 to $18^{\circ} \mathrm{C}$ is often used to model epiphytic growth rate (population doubling time) and spread (insect transfer) from flower to flower (Billing 2000). On the other hand, wetness is scarce and, in fact, under Israeli conditions, this is the limiting factor for pathogen invasion of the host tissue. For example, wetness duration in Rosh Pinna exceeded 10 h/day on only 3 out of the 37 days in 2010; on one-third of the days, wetness duration was $0 \mathrm{~h} /$ day (Fig. 2A).

Another environmental feature that is unique to the spring season in Israel is the occurrence of heat waves, known as "khamsin" or "sirocco." Heat waves are weather events characterized by low relative humidity (minimum $\mathrm{RH}<20 \%$ ) and high air temperature (maximum temperature $>32^{\circ} \mathrm{C}$ ). Heat waves prevail from one to several days and end with a sharp drop in temperature and a rapid increase in humidity often accompanied by rainfall. For example, a heat wave occurred in Rosh Pinna from 3 to 5 April 2010 (Fig. 2A). Fire blight infection episodes often coincide with the termination of heat waves.

With respect to the host, one unique characteristic of the local conditions is the occurrence of autumn blooming (Naor et al. 2006) and autumn infections (Fig. 3A to C). As the blossoms are the host tissue that is most susceptible to infection, fire blight infections may occur in Israel during both spring and autumn. The occurrence of autumn infections was reported by Manulis et al. (1998) and its role in the epidemiology of the disease was studied by Blachinsky et al. (2003). Results implied that autumn infections play a substantial role in fire blight epidemiology in Israel. The progression of fire blight symptoms in perennial branches following spring infections ceased between mid-May and mid-July, and only a small proportion ( 0 to $14.2 \%$ ) of the infections had invaded the trees' main limbs or trunks.
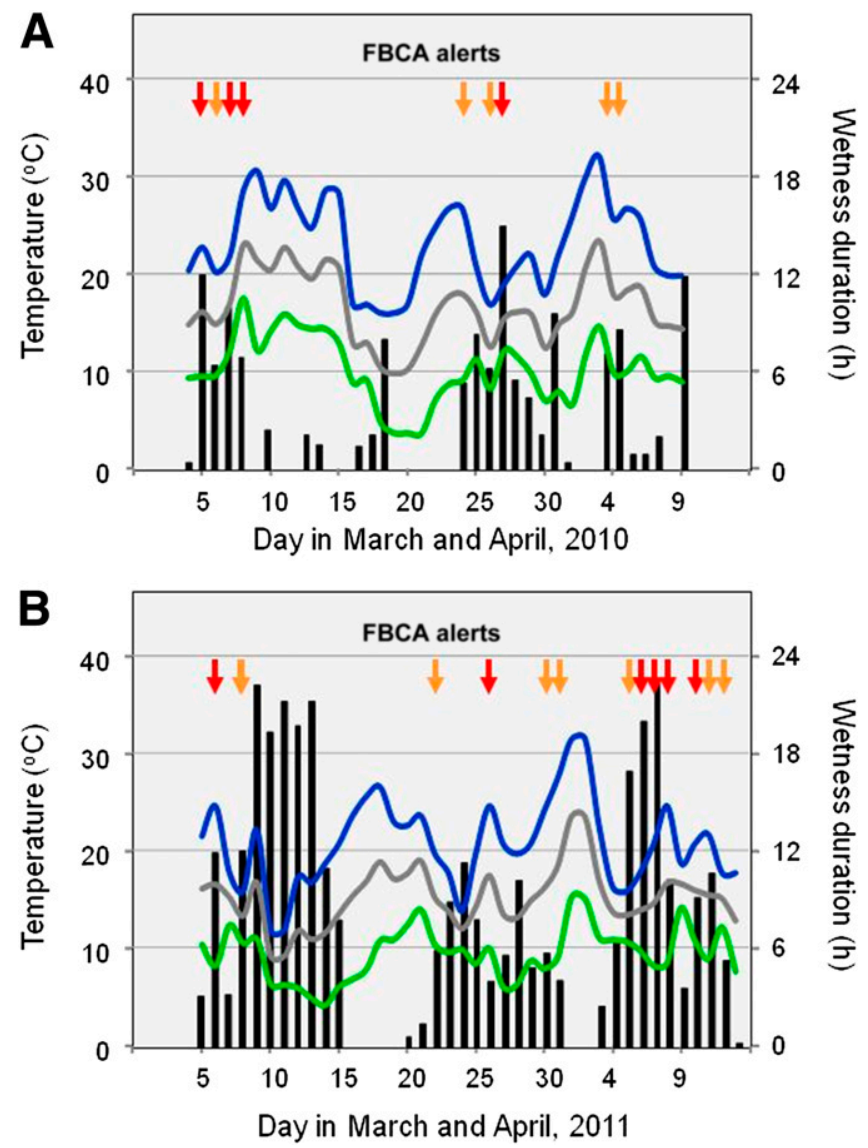

Fig. 2. Weather parameters recorded during the blooming period in Rosh Pinna, Israel, in 2010 (A) and 2011 (B). Blue line: maximum, gray line: mean, green line: minimum daily temperature; bars = daily duration of wetness. Arrows in the upper parts of each graph indicate infection risk days alerted by the fire blight control advisory (FBCA) warning system. Red arrow: severe alert; orange arrow: intermediate alert.
However, following autumn infections, symptoms in perennial branches continued to progress through the winter until the following spring, and most of the autumn infections (50 to $78.5 \%$ ) that developed in susceptible trees had invaded the main limbs or trunks. These infections caused significant economic losses (Fig. 3D and E). Furthermore, the surviving cankers may serve as a source of inocula for the subsequent spring infections.

\section{The Pre-First Fire Blight Pandemic Era (1985 to 1993)}

Fire blight symptoms first developed in an orchard in northern Israel (near Rosh Pinna) in 1985 (Beer et al. 1986; Zutra et al. 1986). Within 3 weeks, the disease developed in other orchards in the same region, as well as in the Yizrael valley (ca. $50 \mathrm{~km}$ away) and in the southern coastal plain (ca. $200 \mathrm{~km}$ away). Initial attempts to eradicate the pathogen included isolating, uprooting, and burning symptomatic trees. Strict sanitation regulations included the disinfestation of working tools, farm vehicles, workers' hands, and their clothing. Nevertheless, these procedures failed, and in the following two seasons, fire blight spread to all pear-production areas in Israel (Shabi and Zutra 1987; Zutra et al. 1986). Accordingly, the disease management strategy changed from eradication to containment and suppression (Beer et al. 1986). To cope with fire blight, growers applied a copper compound before bloom and periodic sprays of streptomycin (up to seven sprays in a season) thereafter, and if fire blight symptoms expressed, pruned the infected tissues to $30 \mathrm{~cm}$ below the visible symptoms on diseased stems. In subsequent years, infections were spatially scattered countrywide. In some cases, epidemics in individual orchards were severe, leading to decreased yields, tree death, and uprooting of individual trees and occasionally, entire orchards. Nevertheless, the intensities of the epidemics regionally and nationally were mild.

\section{The First Israeli Pandemic (1994 to 1996) and the Fire-Man Project (1997 to 2000)}

In 1994 and 1995, severe fire blight epidemics developed in the Samaria region (located in the center of Israel). The epidemics derived from overlooked autumn infections. They led to substantial damage and eventually the uprooting of more than $90 \%$ of the pear orchards in the region. In 1996, a severe pandemic enveloped the country, including the main production area in the north. The pandemic developed despite the fact that growers had followed the precautionary recommendations for disease management, including frequent spray applications of streptomycin during bloom. Following this failure of disease suppression, the sensitivities of E. amylovora isolates to streptomycin were assessed. Streptomycin-resistant strains were recovered from infected blossom clusters and branches from all pear-production areas in the country (Manulis et al. 1998). This situation constituted a serious threat to the Israeli pear industry. First, the wide prevalence of the disease and the severity of the infections in the main production areas endangered future crops. Second, the development of streptomycin-resistant populations precluded further use of that compound. Since streptomycin was the only bactericide registered for suppression of E. amylovora, pear growers in Israel had no other pesticidal alternative. Accordingly, the need for an immediate solution prompted the establishment of an emergency research and development project in 1997, named the "fire blight management (Fire-Man)" project.

Framework of the Fire-Man project. Administrators from the Israeli Fruit Board, the Agricultural Research Organization (ARO), and the Extension Service launched the Fire-Man project. Participants included scientists from research institutes, extension personnel working in fruit tree crop protection and fruit tree production, the Fruit Board of Israel, private consultants, commercial growers, the National Weather Forecasting Service, the Galilee Technology Center, and private companies that manufactured and marketed pesticides. In addition, the project hired workers for special tasks such as scouting, spraying, and computer programming. In total, 20 to 40 individuals participated in the Fire-Man project each year. The Ministry of Agriculture and Rural Development, Fruit Board of Israel, and private pesticide companies funded the research and development efforts. The short-term goal of 
the Fire-Man project was to quickly develop means to enable the pear industry to endure the threat of fire blight in subsequent seasons. A steering committee was chosen and an administrative coordinator nominated to direct the Fire-Man project. A fire blight panel of experts met to cope with various professional issues. In the years following project establishment, all components of disease management protocols were experimentally evaluated and updated.

Reducing the amount of initial inoculum before bloom. Documented efficacies of copper applications before bloom have been inconsistent. Results of two experiments conducted in 1998 in Israel revealed that application of copper hydroxide before and during green tip had no significant effect on disease intensity during bloom (D. Shtienberg et al., unpublished). Analyses of data recorded in commercial orchards corroborated these results (Shtienberg et al. 2000). Based on these data, copper hydroxide applications before bloom were no longer a recommended practice.

Protecting blossoms to prevent infections. Until 1997, the only bactericide registered in Israel for use against E. amylovora was streptomycin. As streptomycin-resistant E. amylovora populations became widespread, there was an urgent need to find an effective alternative. From 1997 to 2001, 45 replicated experiments were conducted in commercial orchards located in all pear-growing regions of the country. These experiments evaluated the efficacy of five antibiotic compounds against E. amylovora. Natural infections developed in 17 of the experiments and in 14 of them ( $31 \%$ success), the data could be analyzed and significant differences were detected among treatments. Oxolinic acid at a concentration of $300 \mu \mathrm{g}$ a.i./ml was highly effective against $E$. amylovora and reduced disease severity significantly in all experiments, as compared with the untreated control (Shtienberg et al. 2001). In addition, six artificial-inoculation experiments corroborated data derived from the natural-infection experiments. Oxolinic acid is a quinolone antibiotic used for management of bacterial diseases on rice and vegetables (Hikichi et al. 1989). The pre- and postinoculation activities of oxolinic acid were determined on blossom clusters sprayed with the bactericide before or after inoculation. Control efficacy on blossom clusters sprayed 1 to 4 days before inoculation, and 1 or 2 days after inoculation, did not differ significantly from that observed on blossoms sprayed on the date of inoculation. Accordingly, oxolinic acid may be applied soon before, or after, the occurrence of an infection episode (Shtienberg et al. 2001).

Pear blossoms open daily during bloom. Thus, blossoms that opened after spraying bactericides were not protected. Consequently, for optimal pesticidal protection, sprays had to be applied frequently with short intervals between applications. However, this was not practical due to the costs of spraying and environmental considerations. Moreover, to lower the probability of resistance development in the pathogen population, spray numbers should be minimized. As the number of infection episodes per year in individual orchards in Israel was limited from one to three (Shtienberg et al. 2000), it was expected that a few properly timed bactericide sprays would adequately protect the blossoms. To find a tool that could predict when infection episodes were most likely to occur, we examined several warning systems developed for fire blight management. The systems were "Maryblyt," which was developed in Maryland, United States (Steiner 1990), "Cougarblight 98C," developed in Washington State, United States (Smith 1999), "BIS95," developed in England (Billing 1999), and the "Fire Blight Control Advisory" (FBCA) system, which was developed in Israel (Shtienberg et al. 1999). All systems were tested in simulation experiments; Maryblyt and FBCA were also tested in 10 orchard experiments with natural infections. In addition, 25 pear growers operated the FBCA system in their orchards experimentally in 2000 (Shtienberg et al. 2003a). Based on the replicated orchard experiments, the simulation experiments, and the experience gained by the commercial growers, it was decided to recommend using the FBCA system. The system was independently operated by commercial growers in 2001 and in subsequent years. Since spray applications occurred just before or after infection episodes, the use of biocontrol agents for disease management was inappropriate. Biocontrol organisms must become established and inhabit the infection site (i.e., the stigmata) before inoculation (Johnson and Stockwell 2000).
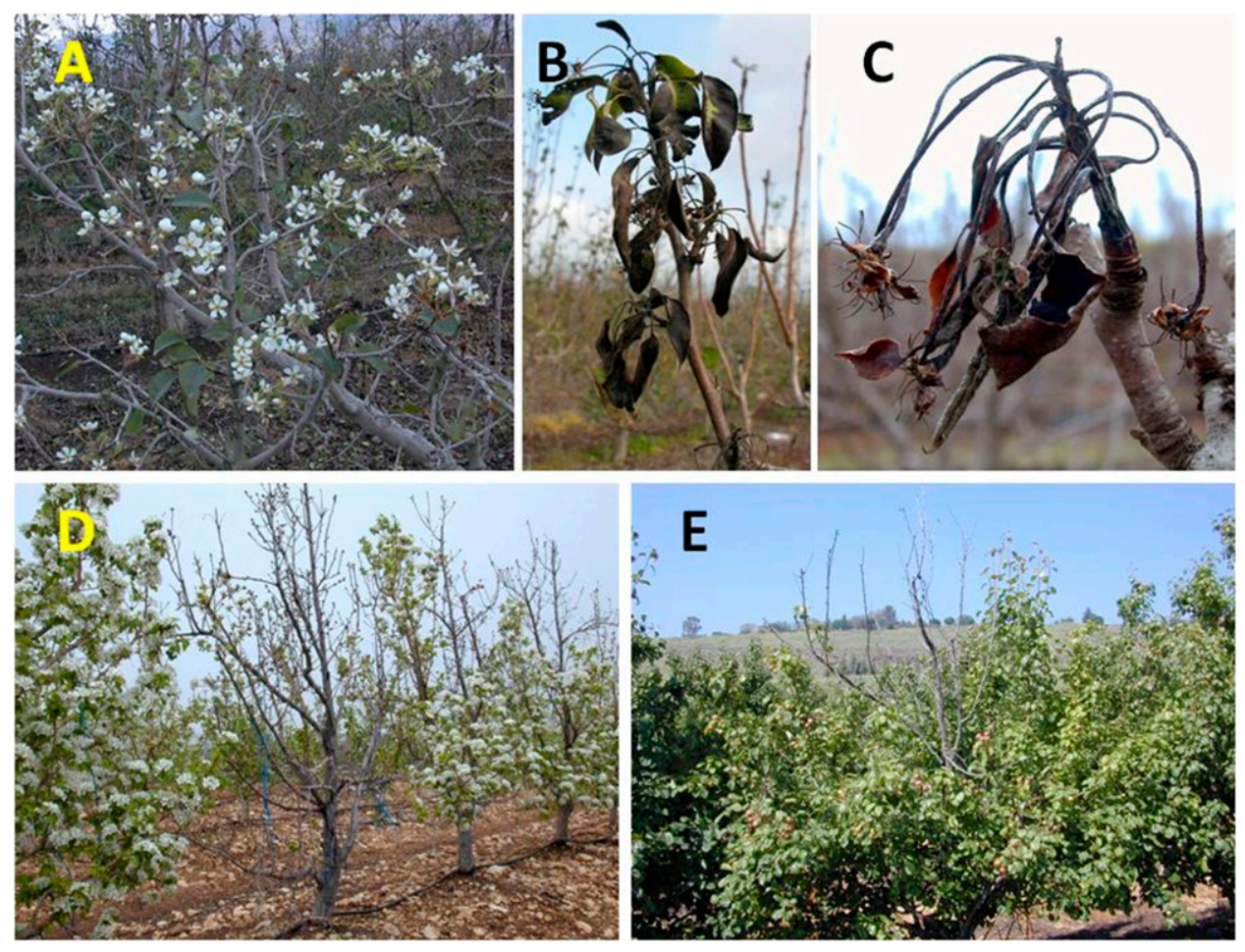

Fig. 3. Autumn bloom in pear orchards suffering from stresses just before the trees enter winter dormancy (A). Under conducive weather conditions and the prevalence of Erwinia amylovora inoculum, autumn blossoms are infected and exhibit fire blight symptoms in the winter (B and $\mathbf{C}$ ). The pathogen advances to the perennial tissues during the winter, often unnoticed, and its devastating effects are seen only in the following spring (D) or early summer (E). 
Sanitation. The expression of fire blight symptoms in an orchard activates the last line of defense in fire blight management, whereby growers remove all infected tissues soon after they observe symptoms. However, sanitation was occasionally inadequate as practiced. In some cases, the excision of tissue promoted shoot growth. If pruning failed to eliminate the bacteria, the altered host physiology induced rapid progress of the pathogen within the woody tissues to worsen the expression of disease. A set of experiments was conducted between 1999 and 2001 to test the significance of factors related to the host (i.e., high or low tree vigor), type of symptomatic tissue (i.e., blossom clusters, annual shoots, perennial shoots, or main limbs), time of pruning (i.e., spring, summer, autumn, or winter), and disease intensity (i.e., few or numerous infections per tree) on the success of the sanitation efforts. The results suggested that the success of sanitation is governed, to a large extent, by the time of pruning and the physiology of the tree. Moreover, they demonstrated that in some cases, it is preferable not to prune at all since the bacteria will remain restricted to the blossom cluster. Based on the results, factors related to all three components of the disease triangle (i.e., pathogen, host, and environment), rather than only the actual presence of diseased tissues, were taken into account and recommendations to Israeli growers were revised and updated (Shtienberg et al. 2003b).

Fire blight prevalence from 1997 to 2000. Fortunately, the weather in spring 1997, the first year of the Fire-Man project, was not conducive to E. amylovora and infections all over the country were negligible. In 1998, weather was conducive to E. amylovora in only some sub regions of pear production. Pear growers, who were still using the previous protocol for fire blight management, were not able to accurately predict the occurrence of infection episodes. In $41 \%$ of the orchards, sprays were either not applied at all during bloom or their applications were improperly timed. In $48 \%$ of the orchards, the sprays protected the blossoms against one infection episode, but not against the other(s). Sprays were effective against all infection episodes in only $11 \%$ of the orchards. In that year, more than 200 ha of pear trees were uprooted due to fire blight infections. In 1999, weather was moderately conducive to E. amylovora. The spray application timing was improved. Spraying was properly timed in $34 \%$ of the orchards, but in $32 \%$ of the orchards spraying did not provide protection against any infection episodes. The year 2000 was the final year of the Fire-Man project. Although the principles of the three-lines-of-defense scheme described earlier (van der Zwet and Beer 1995) remained, the specific recommendations were modified based on the reported results from the Fire-Man project (Fig. 4). By spring 2000, a network of weather stations purchased by the project covered $>95 \%$ of the production area provided the information needed for operating FBCA and the pear growers were encouraged to implement the new management protocols. In 2000, the weather was highly conducive to E. amylovora all over Israel. Orchards that were not protected according to the new management protocols suffered severe epidemics. Nevertheless, nationwide, the severity of fire blight in 2000 was mild.

\section{Between the First and Second Israeli Pandemics (2001 to 2009)}

Coping with $E$. amylovora strains resistant to bactericides. One of the major problems in pesticidal control is a pathogen's ability to develop populations resistant to the active ingredients in use (Brent and Hollomon 2007; Johnson and Stockwell 1998). Since 1998, oxolinic acid has been the only bactericide registered for fire blight management in Israel. As it was expected that resistance to oxolinic acid would develop readily, the response of E. amylovora populations to the compound was monitored yearly. Symptomatic tissues were sampled from commercial orchards and delivered to the testing laboratory. E. amylovora was isolated on CCT medium, identified by PCR if necessary, and plated on CCT medium amended with oxolinic acid at different concentrations. Strains were regarded as resistant if colonies developed on CCT medium amended with oxolinic acid at $50 \mu \mathrm{g}$ a.i./ml (Kleitman et al. 2004). The results were used for implementation of the following anti-resistance strategy. After confirming that $E$. amylovora strains in a specific orchard were resistant to oxolinic acid, an extension officer visited the orchard to estimate and record the severity of fire blight. If symptoms were observed only on lateral branches, removal of branches at least $50 \mathrm{~cm}$ below the symptomatic area was recommended. When symptoms were observed on the main limbs or trunk, the recommendation was to uproot the infected tree. When more than $25 \%$ of the trees had to be uprooted, the officer recommended the removal of the entire orchard. As a precocious measure, PPIS (Plant Protection

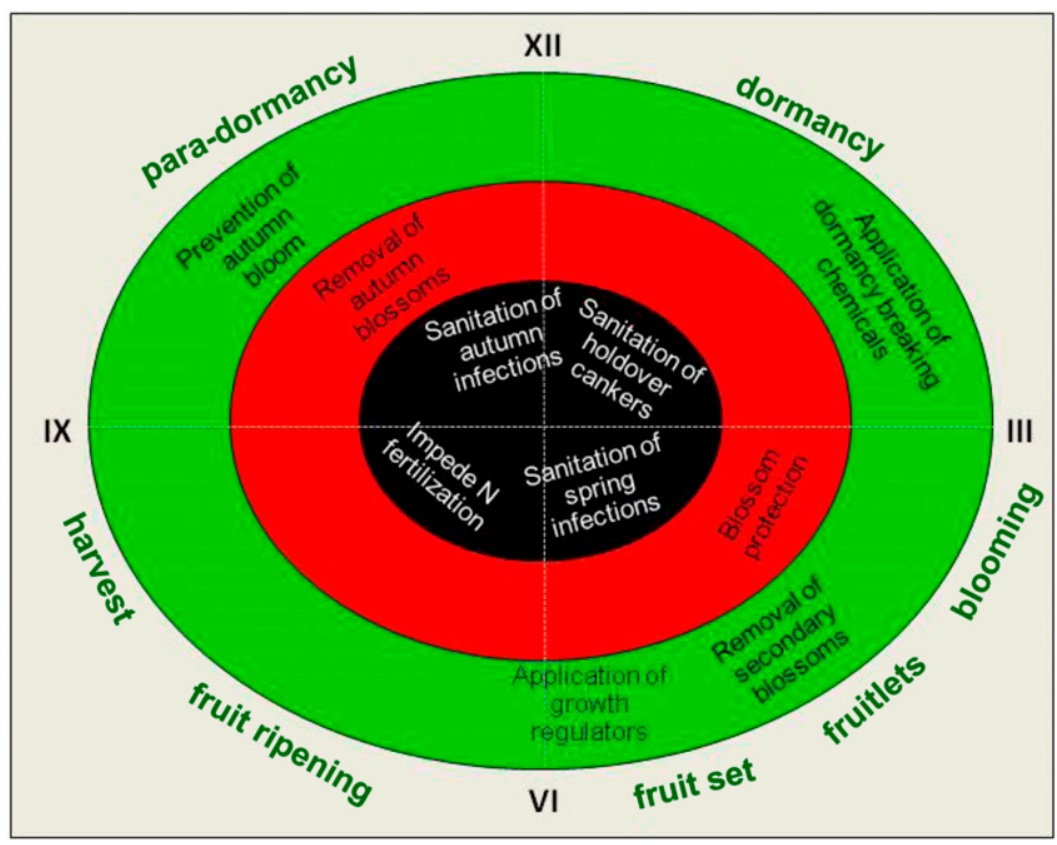

Fig. 4. Fire blight management protocols derived from the Fire-Man project. Activities are carried out year-round and include three lines of defense. Preventive (green) and protective (red) measures are employed regularly in all orchards; curative measures (black) are activated only if fire blight infections occur and disease symptoms are observed in the orchard. 
and Inspection Services) authorities provided special permission to use streptomycin in these orchards in the following year.

Between 2001 and 2009, resistance to oxolinic acid occurred in several orchards each year (Kleitman et al. 2005; Manulis et al. 2003). The location of the orchards did not follow any distinct spatial pattern and resistant strains appeared irrespective of the number of sprays applied (Kleitman et al. 2005). As the parasitic fitness of $E$. amylovora strains resistant to oxolinic acid is less than wild-type strains (Kleitman et al. 2005), the anti-resistance strategy described above was successful. In most cases, E. amylovora strains resistant to oxolinic acid were eliminated promptly and not recorded in the following year. Resistance to streptomycin was occasionally identified but these strains did not persist. E. amylovora strains with dual resistance to oxolinic acid and streptomycin were not detected.

Fire blight prevalence from 2001 to 2008. In 2002 and 2006, weather was highly conducive to fire blight infections and numerous infection episodes occurred. Fortunately, most pear growers implemented the management protocols as instructed and the severity of fire blight was negligible in most orchards. In those years, however, a few growers did not follow the instructions in their orchards and the epidemics were devastating. For example, in 2006, the manager of a pear orchard in a kibbutz located in northern Israel was replaced and the new manager, who had no experience in fire blight management, did not implement the necessary actions. The entire 35-ha production area was severely diseased (Fig. 1C) and most of the trees in that orchard had to be uprooted. It should be noted that in nearby orchards, where growers followed the recommendations, only a few cases of infection were observed and were readily removed by pruning.

\section{The Second Israeli Pandemic (2010 to 2011)}

The chain of events leading to the second pandemic. With time, the number of growers who had no firsthand experience of the destructive nature of fire blight increased, because in the years that followed the first national pandemic, disease intensity was negligible at most farms. Second, all of the plant-protection extension officers who actively participated in the Fire-Man project left the Extension Service. Due to reforms in the Extension Service, their positions were not filled with new plant-protection officers. Therefore, the plant-physiology extension officers took charge of plant-protection problems. Third, funds allocated to fire blight research were cut back and after 2004 there were no active research projects. All of this resulted in a gradual fading of the collective memory regarding the devastating effects of fire blight. This is a natural process, but its outcome was that as time passed, the previously effective and strict disease management protocols were not fully implemented by all growers.

In 2009, weather was highly conducive to fire blight development during blooming. In that year, infected blossom clusters developed in about $40 \%$ of the total production area. In $5.2 \%$ of the area, disease severity was moderate and in $2.5 \%$, it was high. According to the management protocols, growers were to remove infected tissues promptly by cutting 30 to $40 \mathrm{~cm}$ below the visible infection site (Shtienberg et al. 2003b). However, this action would result in the pruning of healthy branches carrying developing fruitlets. In attempt to avoid the losses imposed by this procedure, many growers decided to refrain from cutting the symptomatic tissues. The pathogen continued to progress in the spring and early summer and invaded the perennial tissues. Unrelated to all of this, the quantity of irrigation water allocated to agriculture was reduced in that year as a result of a 4-year drought. Accordingly, pear growers had to reduce irrigation volume by $40 \%$. In most cases, the growers decided to reduce the irrigation after harvest. As a result, the trees faced water shortages that gradually increased with time. From 30 October to 3 November 2009 there was a major rain event with more than $140 \mathrm{~mm}$ in some places, followed by a sharp increase in temperature. These events resulted in massive autumn blooming. Unfortunately, weather in November 2009 was highly conducive to fire blight, leading to massive autumn infections. As indicated earlier, under Israeli conditions, autumn infections are potentially more devastating than those occurring in spring. At that time, officers of the Extension Service recognized the problem and instructed the growers to immediately prune the infected shoots. Some growers followed the recommendations and performed them properly, but many others did not.

The interacting effects of temperature, wetness duration, and inoculum size on the development of fire blight symptoms follows the concept of compensation (Shwartz et al. 2003). According to this concept, conditions that are highly favorable for one of the factors essential for pathogen development may compensate for less favorable conditions for other factors. Weather in spring 2010 was moderately conducive to fire blight (Fig. 2A). However, the exceptionally high amount of initial inoculum surviving from both the spring and autumn infections of 2009 resulted in the most severe fire blight pandemic ever recorded in Israel. It should be noted that infections in orchards where the growers had strictly followed the management protocols in both spring and autumn were negligible.

Coping with the second pandemic. The activity of the fire blight panel resumed in April 2010 to combat the second pandemic. The panel convened regularly to discuss issues related to disease management. One of the first decisions made by the panel was to collect empirical data on the intensity of fire blight in commercial orchards and on the response of E. amylovora strains to oxolinic acid. The data enabled digital mapping of 1,472 orchards in 49 villages covering an area of 1,358 ha (example in Fig. 5A). This area included most of the pear orchards in Israel, and was the first time that digital maps of pear orchards were available. Thus, it was possible to estimate the intensity of the disease: infections were observed in $96.6 \%$ of the surveyed area. Of this area, $7.1 \%$ was severely infected, $38.0 \%$ was moderately infected, and infection in $50.5 \%$ of the area was mild (Fig. 5C). Symptomatic tissues were delivered to a laboratory and the pathogen's response to oxolinic acid was determined according to the procedure described by Manulis et al. (2003). Of the 110 samples taken from pear orchards (each sample represented an orchard), $42 \%$ were resistant to oxolinic acid (Fig. 6). The orchards with resistant strains were scattered throughout the country's production areas. Based on this information, the panel concluded that even if the environment in spring 2011 was unfavorable for infection, the high level of inoculum would devastate the crops. Accordingly, two ambitious working goals were defined: (i) to drastically reduce the amount of inoculum before the 2011 season, and (ii) to eliminate the oxolinic acid-resistant E. amylovora strains during the 2011 season.

Reducing the amount of inoculum before the 2011 season. Since we had accurate information on the intensity of the disease in individual plots, pear orchards were divided into three severity groups. The first contained orchards with severe infections. Because it was impractical to eradicate the disease in these orchards, the decision was to destroy them. The second group was orchards with moderate infections. In these orchards, growers needed to perform strict pruning, in most cases more severe than they were used to. The third severity group was orchards with mild infections and healthy orchards. In these orchards, growers needed to follow the regular pruning protocol. It was decided that these activities should be completed before 1 February 2011. Meeting this ambitious goal required high motivation and full participation from the pear growers. As they were the ones who had to carry out the pruning procedures, it was essential to persuade them to do it of their own free will. Accordingly, the situation was explained to the growers in a series of lectures, meetings, field tours, and periodical extension leaflets.

Another way to encourage full grower participation was financial compensation. The Ministry of Agriculture and Rural Development, together with the Fruit Board, allocated funds to growers who performed the necessary activities. This procedure was operated by KANAT, an agricultural fund. Using the digital maps of infection sites, KANAT inspectors visited the orchards and approved compensation to growers that performed the required activities. By the beginning of January 2011, growers that had decided not to participate were contacted by the PPIS authorities and told they either must uproot their orchards or carry out the required strict sanitation measures. By mid-February $2011,81 \%$ of the orchards that had been severely infected in 2010 were uprooted (78 ha) and strict pruning 
completed in $80 \%$ (413 ha) of the orchards that had been moderately affected.

Eliminating oxolinic acid-resistant $E$. amylovora strains during the 2011 season. The fitness properties of oxolinic acidresistant strains were inferior to those of the wild type (Kleitman et al. 2005). Therefore, it was assumed that if oxolinic acid were removed from commercial use and replaced with the supervised use of streptomycin, the resistant strains would be eradicated. Machteshim Chemical Works (now Adama) imported defined quantities of streptomycin in late winter 2010 and distributed the pesticide to authorized retailers. Based on the digital maps, a list of pear growers and their production areas was prepared by the Fruit Board. In early spring 2011, pear growers were permitted to purchase the quantities of streptomycin needed for two spray
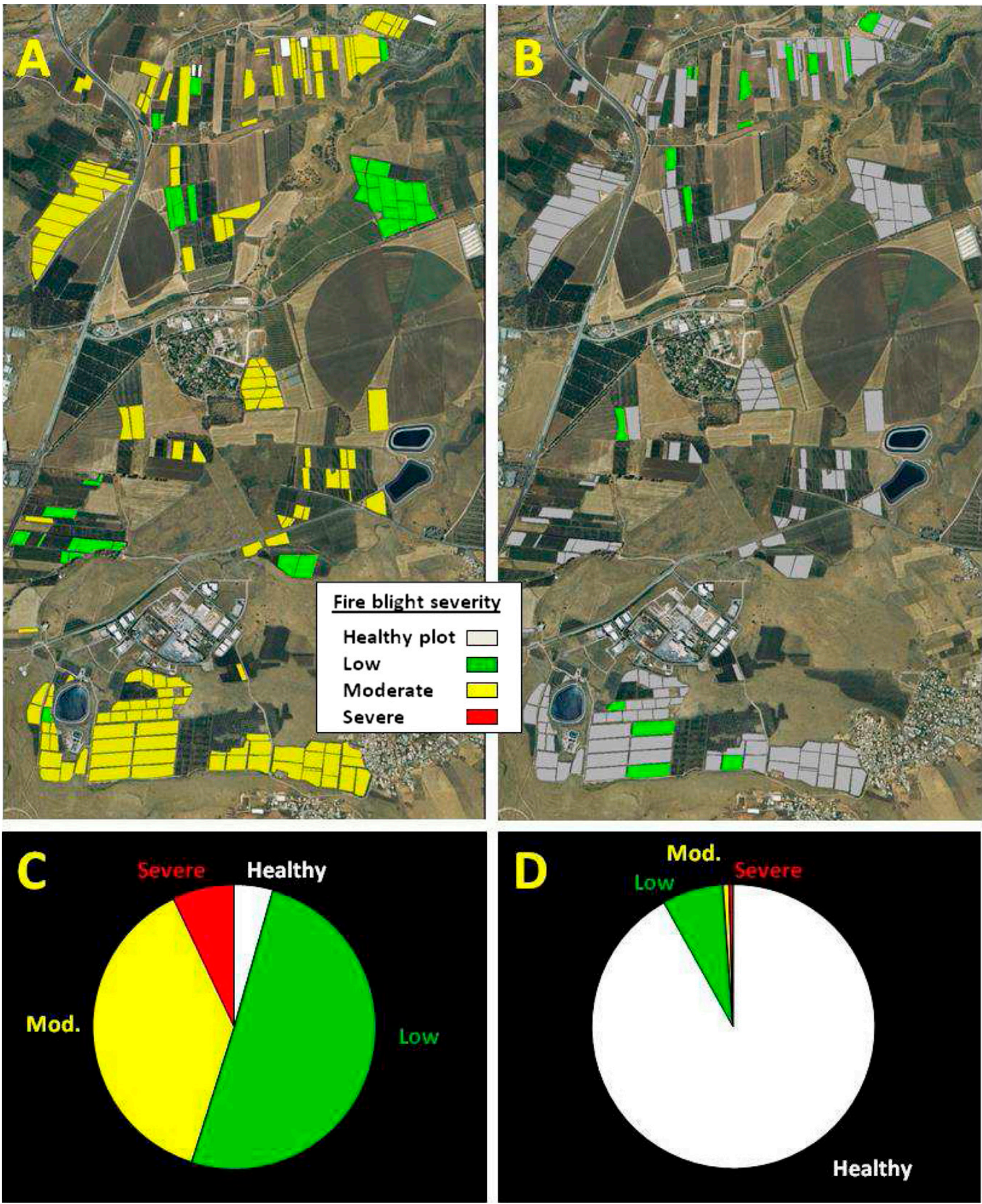

Fig. 5. Maps of the pear orchards in the Rosh Pinna region indicating the severity of the fire blight in 2010 (A) and 2011 (B) in individual orchards. Segmentation of disease intensity into four severity categories on a national scale for 2010 (C) and 2011 (D) was based on the comprehensive surveys conducted in those years. 
applications in their orchards. During the season, the chief extension officer authorized the selling of additional quantities in areas where further sprays were needed. The number of streptomycin sprays in individual orchards in spring 2011 ranged from one to four, with an average of about two sprays per orchard. Samples of symptomatic tissues taken from the orchards in spring 2011 were examined in a laboratory. E. amylovora strains resistant to oxolinic acid were recovered from $45 \%$ of the samples (Fig. 6). The response of these strains to streptomycin was examined, and resistance was found in $13.5 \%$ of the samples. This finding was interesting because streptomycin had not been used commercially in Israel since 1997. Bacteria in eight of the samples were resistant to both oxolinic acid and streptomycin. Symptomatic tissues (mainly perennial branches and limbs) were collected once again in the winter of 2011. As expected, the frequency of oxolinic acid-resistant E. amylovora strains had dropped markedly to only $4.4 \%$. This frequency of resistance was comparable to that found in previous seasons (Kleitman et al. 2005; Manulis et al. 2003) and in spring 2009

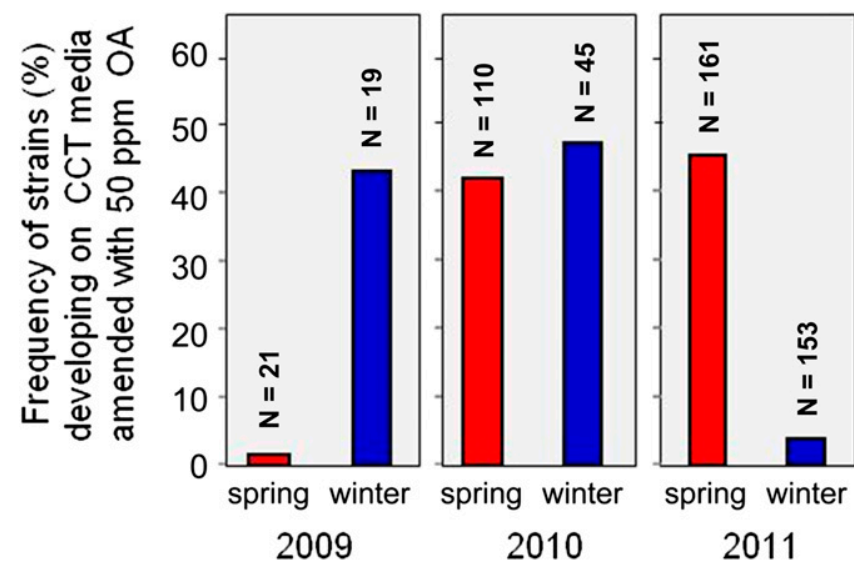

Fig. 6. The prevalence of Erwinia amylovora strains resistant to oxolinic acid (OA) in 2009 to 2011. Bacterial strains were defined as resistant if they developed on CCT medium amended with oxolinic acid at $50 \mu \mathrm{g}$ a.i./ml. $\mathrm{N}=$ number of samples examined in each season; each sample represents one orchard. Resistant strains invading the perennial branches in winter 2009 and 2010 served as the source of initial inoculum to blossoms in the preceding 2010 and 2011 springs.
(Fig. 6). Streptomycin-resistant or dual-resistant strains were not detected.

Fire blight prevalence in 2011. The weather in spring 2011 was highly conducive to fire blight (Fig. 2B). Nevertheless, the worst-case scenario was not realized and the severity of fire blight in spring 2011 was negligible. The disease was not observed in $90.2 \%$ of the production area. Severe infections developed in $0.6 \%$ of the area and moderate infections in $0.8 \%$ of the area. In $8.4 \%$ of the area, infections were observed, but at a low severity (Fig. 5B and D). The differences in disease prevalence and intensity between 2010 and 2011 were remarkable. The question is whether this substantial decrease in disease intensity resulted from the aforementioned management efforts or some other reason, such as a lack of weather conditions favorable for pathogen development, a natural fluctuation in bacterial populations, etc. Not all growers were convinced that it was worthwhile to follow the complicated and troublesome protocols for disease management. Therefore, such orchards were situated next to orchards where growers implemented the management protocols. The stark contrast between these orchards in summer 2011 (Fig. 7) can be attributed to the efforts of the fire blight panel, the pear growers, and the industry as a whole to combat the disease.

\section{Beyond the Second Israeli Pandemic (2012 to date)}

In the seasons succeeding the second national pandemic, oxolinic acid was reinstated for commercial use. The weather was moderately conducive to the pathogen's development but disease intensity, on a national scale, was low. Nevertheless, there were a few scattered orchards (and one region in 2013) with more severe infections. In most cases, it was possible to identify the reasons for inadequate disease suppression. Nevertheless, even in well-managed orchards, pear growers reported a reduced efficacy of oxolinic acid. In the late 1990s, only a few infected blossom clusters were found after application of oxolinic acid, whereas in the late 2000s, infections were more ubiquitous and growers were complaining about the product's effectiveness. The gradual reduction in oxolinic acid efficacy was not related to the occasional development of resistant E. amylovora strains mentioned above. Soon after the introduction of oxolinic acid, the baseline response of E. amylovora strains to the compound was determined in vitro. All strains were completely inhibited when plated on CCT medium amended with a concentration of $1 \mu \mathrm{g}$ a.i. $/ \mathrm{ml}$ oxolinic acid (Manulis et al. 2003). In subsequent years, the ability of E. amylovora strains to develop on CCT medium amended

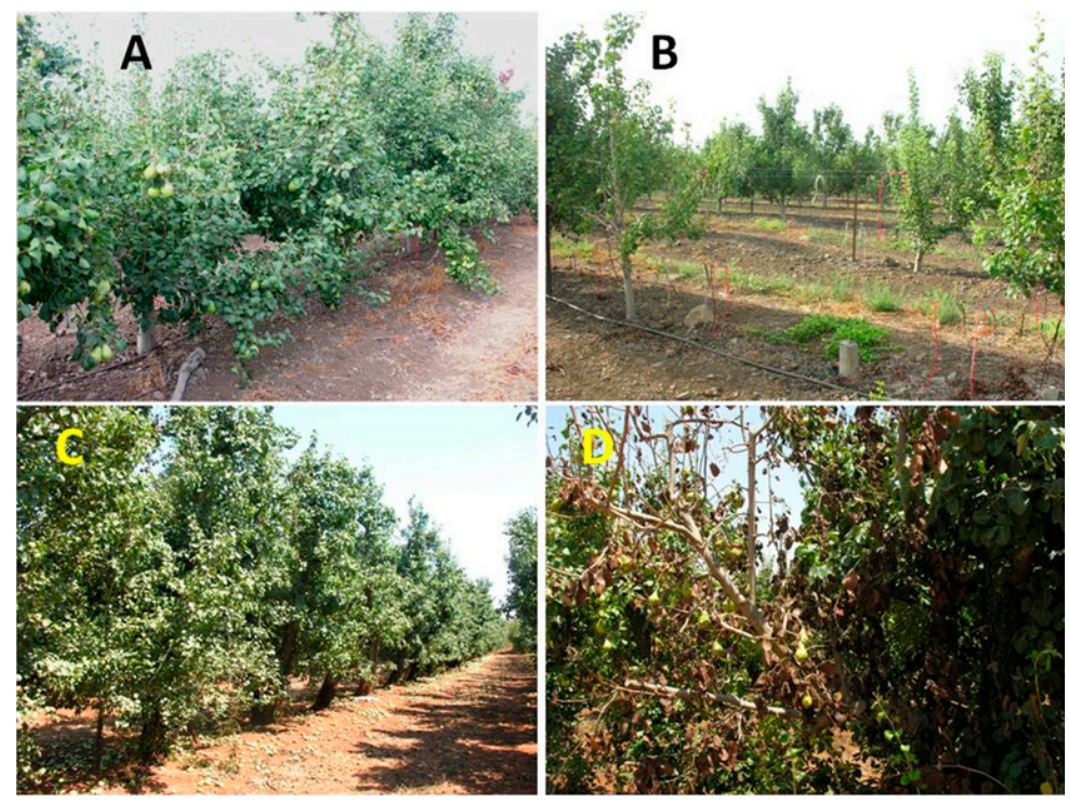

Fig. 7. Photos taken in summer 2011 in orchards where growers strictly implemented fire blight management protocols in winter 2010 and spring 2011 (A and C), and in orchards where the growers did not to implement the recommendations (B and $\mathbf{D})$. All orchards were moderately infected in 2009. Orchards $\mathbf{A}$ and $\mathbf{B}$ were separated by a 6-m pathway; orchards $\mathbf{C}$ and $\mathbf{D}$ by about $100 \mathrm{~m}$. 
with a concentration of $5 \mu \mathrm{g}$ a.i./ml oxolinic acid was recorded. In these tests we followed the experimental procedures described by Manulis et al. (2003). There was a gradual increase in the frequency of samples developing on the medium (Fig. 8), indicating an ongoing shift in the response of the bacterial population to this compound. Developments of multistep resistance of bacteria to antibiotic compounds and of fungi to fungicides are well documented (e.g., Brent and Hollomon 2007; Kosowska-Shick et al. 2009). Browne et al. (2002) reported that the frequency of bacteria populations developing multistep resistance to antibiotics of the quinolone group was higher than that observed for antibiotics of other chemical groups. Oxolinic acid is a quinolone antibiotic (Hikichi et al. 1989).

The gradual decrease in oxolinic acid efficacy called for a solution, and in 2008 the recommended application concentration was increased from 0.15 to $0.2 \%$. In 2012, experiments were initiated to find a substitute product(s). Application of copper tribasic sulfate as a sole product was not effective enough (unpublished data). But, application of $0.1 \%$ copper tribasic sulfate in a tank mix with $0.2 \%$ oxolinic acid did not damage the blossoms and in some cases improved disease suppression as compared with application of either product alone. Accordingly, the tank mix has been recommended since 2014 to slow the further reduction in disease suppression. If a gradual reduction in the efficacy of oxolinic acid continues, this compound will no longer be useful to pear growers in Israel.

\section{Conclusions and Future Perspectives}

In the mid-1990s, much was already known about the fire blight pathogen, the etiology and the epidemiology of the disease, and how to manage it properly. Management protocols had been developed in many countries and were effectively used there. The management protocols that were implemented in Israel soon after the disease's invasion in 1985 were "imported" from other countries (Beer et al. 1986). These management protocols were ineffective in the 1994 to 1996 pandemic. It turns out that the seemingly minor differences in host $\times$ pathogen $\times$ environment interactions that exist between Israel and other places had a tremendous effect on the epidemics. Thus, the impetus for the first national pandemic was lack of knowledge on the epidemiology of the disease under local conditions. The main contribution of the Fire-Man project was the identification of the host $\times$ pathogen $\times$ environment interactions that are unique to the local conditions. Apparently, the local management protocols developed in the Fire-Man project (Fig. 4) was similar to the management protocols employed elsewhere (Beer et al. 1986; van der Zwet and Beer 1995; van der Zwet et al. 2012). However, in practice, the management protocols were fitted to the unique local conditions and the details were very different. Specifics of these differences were briefly described herein and are detailed in publications about the bactericides' efficacies (Shtienberg et al. 2001), spray timing and use of warning systems (Shtienberg et al. 1999, 2003a), pruning procedures (Shtienberg et al. 2003b), management of resistance (Kleitman et al. 2004, 2005), and the significance of

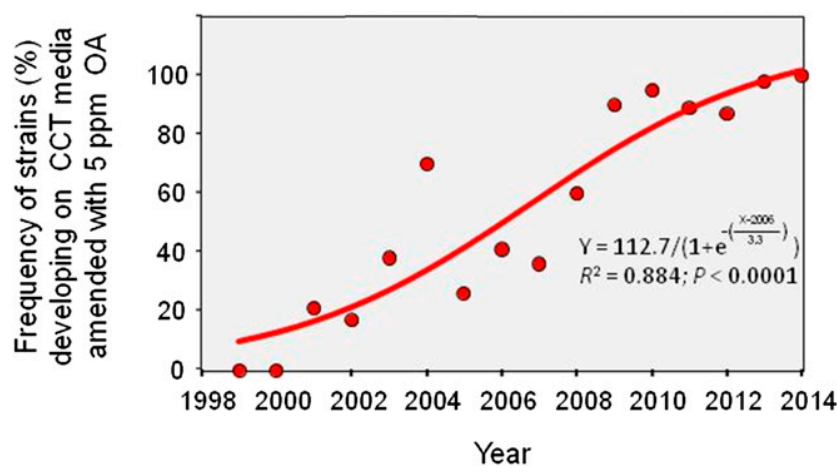

Fig. 8. Changes in the frequency of Erwinia amylovora strains developing on CCT medium amended with $5 \mu \mathrm{g}$ a.i./ml oxolinic acid $(\mathrm{OA})$ over time. Oxolinic acid was introduced for commercial use in 1998. autumn blooming (Blachinsky et al. 2003, 2006). Our experience regarding the necessity to match the general knowledge about the fire blight pathosystem to local conditions is relevant to other places as well. This implies that local studies are essential, even in pathosystems that seem to be well understood at a global level.

The second national pandemic was the result of inappropriate implementation of existing knowledge organized in the framework of management protocols. Growers who implemented the management protocols properly experienced mild infections. This observation raises a key question: why, in 2010, did most pear growers fail to implement the management protocols that had proven so effective in previous seasons? The answer to that question is not obvious. The fact that the previous national pandemic had occurred 14 years prior (in 1996) probably clouded the collective memory of the devastating effects of this disease. In this regard, the success of the management protocols set it up for failure. The fact that all of the plant protection officers who had participated in the Fire-Man project during the first national pandemic left the Extension Service, and that the researchers involved in that project had shifted to study other pathosystems, probably assisted in the lack of awareness of the danger. It is likely that our local experience regarding the necessity to continuously remind pear growers about the potentially devastating effects of fire blight is relevant in other places as well.

The pear industry in Israel has changed markedly over the last 30 years. Fire blight has not been the only reason for these changes; yield load, fruit quality, consumer preferences, and other factors related to the profitability of the crop have also contributed. Nevertheless, the national pandemics of fire blight undoubtedly contributed to these changes. In the mid-1980s, the pear production area was about 1,500 ha and about $20 \%$ of the pear orchards were located in the central and southern parts of the country. Over the years, the area has remained more or less the same but since the 2000s the entire production area has shifted to the north. Pear orchards in other parts of the country have been uprooted. In the mid-1980s, production was dominated by small, family-owned businesses cultivating less than 5 ha each. Since the 2000s, collectives or large businesses cultivating more than 10 ha each dominate. These two changes coincided with the first national pandemic. The second national pandemic occurred only 4 years ago, and it is too early to recapitulate its impact on the industry; nevertheless, it seems that today we are experiencing another wave of changes. Coping with fire blight requires specialization and professionalism. Thus, the disease imposes selection pressure that leads to survival of only the skilled growers. The unqualified growers will not be able to cope with the disease and will eventually uproot their pear orchards and shift to other, less challenging crops. Furthermore, it is likely that the gradual decrease in oxolinic acid efficacy will eventually preclude its use. With the unavailability of new effective bactericides to protect the blossoms, growers are being urged to use alternative methods to cope with the disease. For example, avoidance: production in areas at altitudes of less than $400 \mathrm{~m}$ (for example, in the western Galilee and the Hula valley), where blooming coincides with weather conditions that are favorable to pathogen infection, will decrease. Shifting production to altitudes above $700 \mathrm{~m}$ (for example, the upper Galilee and the Golan Heights), where blooming occurs later, will enable escaping the weather conditions favoring pathogen infection. Similarly, changing the tree shaping in the newly planted orchards from the traditional Palmette training system that promotes host growth and pathogen progression into the perennial branches to the Stindale training system, which inhibits host growth and pathogen progression, will decrease the hazards imposed by fire blight. The use of other measures, such as biocontrol agents, compounds that induce host resistance, and resistant cultivars adapted to the local conditions, will increase as well.

The take-home message of the Israeli fire blight story is that the battle against this hazardous disease is neverending. The biological processes affecting the host and the pathogen, changes in the environment, the psychological processes affecting the growers, and the continuous changes in the agribusiness markets govern the dynamics and complexity of this pathosystem. Thus, in some years growers are able to adequately suppress the disease but in others 
the pathogen overcomes management efforts and severe outbreaks occur. The latter could be minimized if growers have a full understanding of the management protocols and apply them rigorously.

\section{Literature Cited}

Beer, S. V. 1990. Fire blight. Pages 61-63 in: Compendium of Apple and Pear Diseases. A. L. Jones, and H. S. Aldwinckle, eds. APS Press, St. Paul, MN.

Beer, S. V., Shabi, E., and Zutra, D. 1986. Fire blight in Israel - 1985. Observations and recommendations. EPPO Bull. 16:639-646.

Billing, E. 1974. The effect of temperature on the growth of the fire blight pathogen, Erwinia amylovora. J. Appl. Bacteriol. 37:643-648.

Billing, E. 1999. Fire blight risk assessment: Billing's integrated system (BIS) and its evaluation. Acta Hortic. 489:399-405.

Billing, E. 2000. Fire blight risk assessment systems amd models. Pages 293-318 in: Fire Blight: the Disease and its Causative Agent, Erwinia amylovora. J. L. Vanneste, ed. CABI Publishing, Wallingford, UK.

Blachinsky, D., Shtienberg, D., Oppenheim, D., Zilberstaine, M., Levi, S., Zamski, E., and Shoseyov, O. 2003. The role of autumn infections in the progression of fire blight symptoms in perennial pear branches. Plant Dis. 87:1077-1082.

Blachinsky, D., Shtienberg, D., Zamski, E., Weinthal, D., and Manulis, S. 2006. Effects of pear tree physiology on fire blight progression in perennial branches and on expression of pathogenicity genes of Erwinia amylovora. Eur. J. Plant Pathol. 116:315-324.

Bogdanove, A., Kim, J. F., and Beer, S. V. 2000. Disease specific genes of Erwinia amylovora: keys to understanding pathogenesis and potential targets for disease control. Pages 163-177 in: Fire Blight: the Disease and its Causative Agent, Erwinia amylovora. J. L. Vanneste, ed. CABI Publishing, Wallingford, UK.

Brent, K. J., and Hollomon, D. W. 2007. Fungicide Resistance: the Assessment of Risk. FRAC Monograph No. 2, 2nd Ed. Printed by Aimprint, UK.

Browne, F. A., Clark, C., Bozdogan, B., Dewasse, B. E., Jacobs, M. R., and Appelbaum, P. C. 2002. Single and multi-step resistance selection study in Streptococcus pneumoniae comparing ceftriaxone with levofloxacin, gatifloxacin and moxifloxacin. Int. J. Antimicrob. Agents 20:93-99.

Hikichi, Y., Noda, C., and Shimizu, K. 1989. Oxolinic acid. Jpn. Pestic. Inf. 55:21-23. Johnson, K. B. 2000. Fire blight of apple and pear. The Plant Health Instructor. Online. Johnson, K. B., and Stockwell, V. O. 1998. Management of fire blight: a case study in microbial ecology. Annu. Rev. Phytopathol. 36:227-248.

Johnson, K. B., and Stockwell, V. O. 2000. Biological control of fire blight. Pages 319-337 in: Fire Blight: the Disease and its Causative Agent, Erwinia amylovora. J. L. Vanneste, ed. CABI Publishing, Wallingford, UK.

Kleitman, F., Manulis, S., Kritzman, G., Oppenheim, D., Zilberstaine, M., and Shtienberg, D. 2004. Use of a diagnostic medium for in situ determination of the response of Erwinia amylovora strains to bactericides. Phytoparasitica 32:127-131.

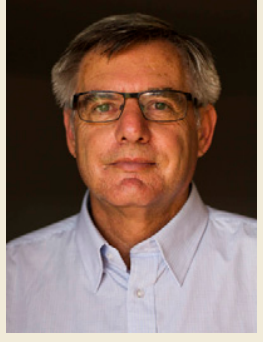

Dani Shtienberg

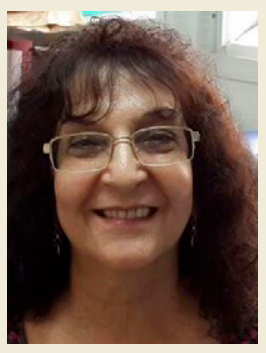

Shulamit Manulis-Sasso

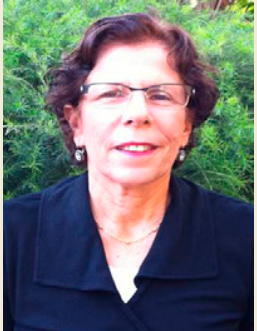

Miriam Zilberstaine

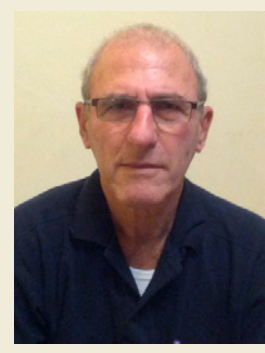

Dov Oppenheim

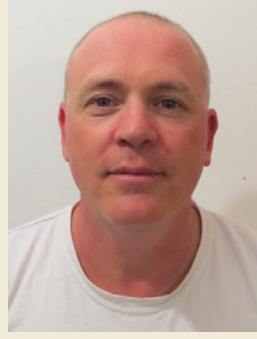

Hagai Shwartz
Dr. Shtienberg received his B.Sc. and M.Sc. in agriculture (plant pathology) and completed his Ph.D. studies (plant pathology) in 1987 at The Hebrew University of Jerusalem (HUJ), Israel. After postdoctoral positions at Cornell University and at the HUJ, he was employed in 1991 at the Agricultural Research Organization, Volcani Center, Bet Dagan, Israel, where he was promoted to the rank of A+ (equivalent to full professor) in 1999. He served as president of the Israeli Phytopathological Society (1994 to 1996), head of the Departments of Nematology (2000 to 2001) and Plant Pathology and Weed Research (2006 to 2008). His research interests lie in the area of botanical epidemiology, disease management, development of decision support systems, IPM, and modeling. He has been involved in studies of more than 20 diverse pathosystems including bacterial, fungal, and oomycete pathogens and developed numerous decision support systems aimed at coping with plant disease epidemics. He has published more than 110 scientific papers and review articles in various international journals and 20 book chapters. He has been the major supervisor of more than 25 graduate students in plant pathology at the HUJ.

Dr. Manulis-Sasson received her Ph.D. degree in Botany (plant pathology) at Tel-Aviv University, Israel. After a post-doctorate period with Dr. Noel Keen at University of California, Riverside she joined, in 1988, the Department of Plant Pathology at the Agricultural Research Organization, Volcani Center, Bet Dagan, Israel. In 2003, she was promoted to senior scientist (equivalent to full professor). Her research is mainly directed at development and implementation of molecular diagnostic procedures for detecting pathogenic bacteria in ornamentals, vegetables and fruit trees. She dedicated much of her time to basic research in molecular plant-microbe interactions on the tumorigenic bacterium Pantoea agglomerans pathogenic on gypsophila and beet and Clavibacter michiganensis pathogenic on tomato.
She has published more than 85 scientific papers and review articles and has been the supervisor of more than 30 graduate students in plant pathology at Tel Aviv and the Hebrew Universities. She served as the president of the Israeli Phytopathological Society and was the Head of the department of Plant Pathology and Weed Research.

Dr. Zilberstaine received her Ph.D. degree in plant pathology in 1989 at The Hebrew University of Jerusalem, Israel. She is a specialist of plant protection, with experience of more than 25 years in fruit trees. Dr. Zilberstaine leads an Area Wide IPM project against MedFly (Ceratitis capitata) and other fruit trees' pests in Israel and in developing countries. She coordinates the field extension activities against Fire-blight in Pears in Israel since 2000.

Mr. Oppenheim received his B.Sc. in biology at the Hebrew University of Jerusalem (HUJ) in 1984. From 1984 to 1987 he managed issues concerned with plant protection of deciduous fruit trees in Kibbutz Malkiya's (Upper Galilee, Israel). In the next 22 years (1988-2010) he was employed by the Israeli Ministry of Agriculture and Rural Development, Extension Service, as a regional extension crop protection specialist for deciduous fruit crops in the Galilee-Golan region and state specialist for pome crop protection. He has published more than 20 popular papers in the Israeli growers' journal and a guide book for IPM methods in pome fruits and participated in more than 100 other professional and scientific documents.

Mr. Shwartz received his M.Sc. degree in plant pathology from The Hebrew University in Jerusalem in 2001. His thesis was on epidemiology and rational management of fire blight in pears. Currently, he runs an orchard where he specializes in Rosacea fruit trees. He is a member of the board dealing with pear production which is part of the Israeli Plants Production and Marketing Board and coordinates the fire blight panel of experts since 2010 
Kleitman, F., Shtienberg, D., Blacjinsky, D., Oppenheim, D., Zilberstaine, M., and Manulis, S. 2005. Erwinia amylovora populations resistant to oxolinic acid in Israel: prevalence, persistence and fitness. Plant Pathol. 54:108-115.

Kosowska-Shick, K., Clark, C., Pankuch, G. A., McGhee, P., Dewasse, B., Beachel, L., and Appelbaum, P. C. 2009. Activity of telavancin against Staphylococci and Enterococci determined by MIC and resistance selection studies. Antimicrob. Agents Chemother. 53:4217-4224.

Loescher, W. H. 1987. Physiology and metabolism of sugar alcohols in higher plants. Physiol. Planta. 70:553-557.

Manulis, S., Kleitman, F., Shtienberg, D., Shwartz, H., Oppenheim, D., Zilberstaine, M., and Shabi, E. 2003. Changes in the sensitivity of Erwinia amylovora populations to streptomycin and oxolinic acid in Israel. Plant Dis. 87:650-654.

Manulis, S., Zutra, D., Klitman, F., Dror, O., David, I., Zillberstaine, M., and Shabi, E. 1998. Distribution of streptomycin-resistant strains of Erwinia amylovora in Israel and occurrence of blossom blight in the autumn. Phytoparasitica 26:223-230.

Naor, A., Stern, R., Flaishman, M., Gal, Y., and Peres, M. 2006. Effects of postharvest water stress on autumnal bloom and subsequent-season productivity in mid-season "Spadona” pear. J. Hortic. Sci. Biotechnol. 81:365-370.

Norelli, J. L., Jones, A. L., and Aldwinckle, H. S. 2003. Fire blight management in the twenty-first century: using new technologies that enhance host resistance in apple. Plant Dis. 87:756-765.

Shabi, E., and Zutra, D. 1987. Outbreaks of fire blight in Israel in 1985 and 1986. Acta Hortic. 217:23-30.

Sherman, V. T. 2000. Epidemiology of fire blight. Pages 9-36 in: Fire Blight: the Disease and its Causative Agent, Erwinia amylovora. J. L. Vanneste, ed. CABI Publishing, Wallingford, UK.

Shtienberg, D., Kritzman, G., Herzog, Z., Oppenheim, D., Zillberstaine, M., and Blatchinsky, D. 1999. Development and evaluation of a decision support system for management of fire blight in pears. Acta Hortic. 489: 385-392.

Shtienberg, D., Oppenheim, D., Herzog, Z., Zillberstaine, M., and Kritzman, G. 2000. Fire blight of pears in Israel: infection, prevalence, intensity and efficacy of management actions. Phytoparasitica 28:361-374.
Shtienberg, D., Zillberstaine, M., Oppenheim, D., Herzog, Z., Manulis, S., Shwartz, H., and Kritzman, G. 2001. Efficacy of oxolinic acid and other bactericides in suppression of Erwinia amylovora in pear orchards in Israel. Phytoparasitica 29:143-154.

Shtienberg, D., Shwartz, H., Oppenheim, D., Zillberstaine, M., Herzog, Z., Manulis, S., and Kritzman, G. 2003a. Evaluation of local and imported fire blight warning systems in Israel. Phytopathology 93:356-363.

Shtienberg, D., Zillberstaine, M., Oppenheim, D., Levi, S., Shwartz, H., and Kritzman, G. 2003b. New considerations for pruning in management of fire blight in pears. Plant Dis. 87:1083-1088.

Shwartz, H., Shtienberg, D., Vintal, H., and Kritzman, G. 2003. The interacting effects of temperature, duration of wetness and inoculum size on the infection of pear blossoms by Erwinia amylovora, the causal agent of fire blight. Phytoparasitica 31:174-187.

Smith, T. J. 1999. Report on the development and use of Cougarblight 98C-a situation specific fire blight risk assessment model for apple and pear. Acta Hortic. 489:429-436.

Steiner, P. W. 1990. Predicting apple blossom infections by Erwinia amylovora using the MARYBLYT model. Acta Hortic. 273:149-158.

Thomson, S. V. 2000. Epidemiology of fire blight. Pages 9-36 in: Fire Blight: the Disease and its Causative Agent, Erwinia amylovora. J. L. Vanneste, ed. CABI Publishing, Wallingford, UK.

van der Zwet, T., and Beer, S. V. 1995. Fire Blight-Its Nature, Prevention, and Control: A Practical Guide to Integrated Disease Management. Agricultural Information Bull. No. 631. U.S. Dept. Agric.

van der Zwet, T., Orolaza-Halbrendt, N., and Zeller, Z. 2012. Fire Blight: History, Biology, and Management. APS Press, St. Paul, MN.

Vanneste, J. L., ed. 2000. Fire Blight: The Disease and its Causative Agent, Erwinia amylovora. CABI Publishing, Wallingford, UK.

Vanneste, J. L., and Eden-Green, S. 2000. Migration of Erwinia amylovora in host plant tisues. Pages 73-83 in: Fire Blight: the Disease and its Causative Agent, Erwinia amylovora. J. L. Vanneste, ed. CABI Publishing, Wallingford, UK.

Zutra, D., Shabi, E., and Lazarovits, G. 1986. Fire blight on pear, a new disease in Israel. Plant Dis. 70:1071-1073. 